\title{
Research on the Relationship Between Executive Characteristics and Enterprise Accounting Information Quality-A-Share-Based Entertainment Media Company
}

\author{
Zhang Jiaqi ${ }^{1, a}$, Xin Chenyuan ${ }^{2, b,{ }^{*}}$ and Gao Qi ${ }^{3, c}$ \\ ${ }^{1}$ Shanghai Customs College, China \\ ${ }^{2}$ Shanghai Customs College, China \\ ${ }^{3}$ Shanghai Customs College, China \\ a18221218862@163.com, b957618117@qq.com, ’gaoqi@shcc.edu.cn \\ ${ }^{*}$ Corresponding author
}

\begin{abstract}
Keywords: executive characteristics, quality of accounting information disclosure, listed company,
\end{abstract} entertainment media industry

\begin{abstract}
In recent years, there are many problems in the entertainment media industry. Because of its own characteristics and its high attention in the daily life of the nation, the quality of accounting information disclosure of the entertainment media industry not only affects the owners' supervision over the operators, but also affects the confidence of the outside world in the stability of the market. Aiming at the problem-prone entertainment media industry, this paper, based on the existing theories and relevant literatures, takes Shenzhen entertainment media industry A-share empirical data from 2013 to 2017 as the research sample, and explores the impact mechanism of executive characteristics (executive gender, political background, educational background, age) on the quality of accounting information disclosure.
\end{abstract}

\section{Introduction}

The executive characteristics of entertainment media industry are more complex than other industries, because the threshold is relatively low, personal background experience is different, so there will be great differences in corporate decision-making. From the perspective of executive characteristics, we can study the difference in the quality of accounting information better. Based on the data of A-share listed companies in Shenzhen entertainment media industry, this paper studies the impact of executive characteristics on the quality of accounting information from the corporate level, and puts forward relevant suggestions and countermeasures for the development of enterprises.

\section{Literature Review}

Yu Yiying et al. (2018) pointed out in the study of the relationship between executive characteristics and accounting information quality of A-share listed companies in Shenzhen Stock Exchange that: There is a significant positive correlation between the existence of female executives and the quality of accounting information disclosure; The educational level of senior managers is also proportional to the quality of accounting information. At the same time, Ran and Guanggui (2014) pointed out that supervisors with accounting or academic background, supervisor compensation and female supervisors are the continuous driving factors of improving the quality of accounting information in China. Guo Li (2018) pointed out that there was a significant positive relationship between executive education, age, team size and the quality of information disclosure in the aspects of executive characteristics, property rights and the quality of information disclosure. 


\section{Theoretical analysis}

Gender will have many effects on risk preference, logical thinking, value orientation and so on. Generally speaking, female managers are more cautious, more inclined to make less risky decisions in the process of corporate governance, and less likely to disclose non-standard behavior. The investment of "political connection" has a very similar return with the investment of enterprise's production factors. Entrepreneurs often take the initiative to maintain the political connection in order to maximize the profit of the enterprise, which leads to many abnormal economic phenomena and polarization between different enterprises. According to data from previous studies, executives with political backgrounds act more rigorously than those without political backgrounds. As far as executive qualifications are concerned, senior executives with higher academic qualifications are more likely to use scientific and rigorous methods to assess decision-making risks, and can consider the consequences of various decisions objectively and rationally, so they will pay more attention to the quality of accounting information disclosure. Psychologist's research indicated that as the senior personnel grow older, their cognitive ability will decline, leading to lack of confidence in making decisions, and they tend to avoid risks, so their strategic choice will lead to more prudent disclosure of accounting information and lower probability of making irregular disclosure behavior.

\section{The Research and Design of Executive Characteristics and Accounting Information Quality}

\subsection{Sample Selection}

According to the research needs and considering the limitations of less data, we select all the A-share raw data of Shenzhen entertainment industry (including catering, KTV, etc.) as the data sample in Cathay Pacific Security database from 2013 to 2017, and exclude ST, * ST companies, 59 in total, 295 pieces of data.

\subsection{Research hypothesis}

First hypothesis (H1): In the entertainment industry, the proportion of female executives in a company is proportional to the quality of accounting disclosure.

Second hypothesis (H2): In the entertainment industry, executives with political backgrounds play a positive role in the quality of corporate accounting information disclosure.

Third hypothesis (H3): In the entertainment industry, executive education is proportional to the quality of accounting information disclosure.

Fourth Hypothesis (H4): In the entertainment industry, the age of executives is proportional to the quality of accounting disclosure.

\subsection{Variable Definition}

Table 1 Variable Definition

\begin{tabular}{|l|l|l|l|}
\hline Variable property & Variable Name & Symbols & Variable Definition \\
\hline Explained variable & $\begin{array}{l}\text { Quality of accounting } \\
\text { information } \\
\text { disclosure }\end{array}$ & Disc & $\begin{array}{l}\text { Excellent is 3, good is 2, qualified is 1, } \\
\text { unqualified is 0 }\end{array}$ \\
\hline \multirow{2}{*}{$\begin{array}{l}\text { Explanatory } \\
\text { variable }\end{array}$} & Gender & Gen & Percentage of women in senior management \\
\cline { 2 - 4 } & Age & Age & Average age of senior management team \\
\cline { 2 - 4 } & $\begin{array}{l}\text { Educational } \\
\text { background }\end{array}$ & Edu & $\begin{array}{l}\text { Average academic qualifications of } \\
\text { executive members. Among them, 1 is } \\
\text { secondary school or below, 2 is junior } \\
\text { college, 3 is undergraduate, 4 is master, and } \\
5 \text { is doctor or above }\end{array}$ \\
\cline { 2 - 4 } & Political context & Background & $\begin{array}{l}\text { Average political background. In which } \\
\text { there is a political background of 1 and no } \\
\text { political background of 0 }\end{array}$ \\
\hline Control variable & Profitability & Roa & Return on Total Assets of the Company \\
\cline { 2 - 4 } & Asset-liability ratio & ZF & Asset-liability ratio \\
\hline
\end{tabular}




\subsection{Model design}

Because the explained variables in this paper are ordered variables, the Orderd Logit model is applied. At that same time, the follow models are construct according to the above analysis to test the hypothesis: $\quad$ Disc $=\beta 0+\beta 1 \mathrm{Gen}+\beta 2 \mathrm{Edu}+\beta 3$ background $+\beta 4$ Age $+\beta 5 \mathrm{Size}+\beta 6 \mathrm{Big} 1+\beta 7 \mathrm{Roa}+\beta 8 \mathrm{Dual}+\mu$ Among them $\beta 0$ is the intercept term, $\beta 5-\beta 8$ is regression coefficient, $\mu$ is regression residual.

\section{Empirical Results and Analysis}

\subsection{Descriptive statistical analysis}

The proportion of female executives ranged from 0 to 1.142 , with an average of 0.328 . This shows that the proportion of female executives in listed companies in the entertainment industry is still low. The minimum age of senior executives was 38.5, the maximum was 55.95, the average was 46.925, and the overall entertainment industry was relatively young. The average political background is 0.288 , and executives' attention to political background weakens in all entertainment industries. The minimum value of education is 0 , the maximum value is 4.66 , and the mean value is 3.311 , which is in line with the reality of low threshold of education in the entertainment industry. The other variables are in the normal range.

\subsection{Pearson Correlation analysis}

Political and educational background, age and the quality of accounting information disclosure are positively correlated and significant, while executive gender and the quality of accounting information are negatively correlated and not significant, which preliminarily verifies Hypothesis Two, Hypothesis Three and Hypothesis Four. Overall, the correlation coefficients between the variables are less than 0.5 , so there is no multicollinearity.

\subsection{Multiple regression analysis}

Table 2 shows the results of the regression analysis. It is found that gender, educational background and the quality of accounting information disclosure are not related, political background, age and the quality of accounting information disclosure are positively related and significant, but the significance is not strong. Assumption two, Assumption four.

Table 2 Multiple regression

\begin{tabular}{r|rrrrrr}
\hline Disc & Coef. & Std. Err. & $z$ & P $>|z|$ & [95\% Conf. Interval] \\
\hline Female & -.404965 & .6429582 & -0.63 & 0.529 & -1.66514 & .8552099 \\
Background & .5644761 & .2877883 & 1.96 & 0.050 & .0004214 & 1.128531 \\
Edu & .6009739 & .3144149 & 1.91 & 0.056 & -.015268 & 1.217216 \\
Age & .0892134 & .0384704 & 2.32 & 0.020 & .0138127 & .1646141 \\
Roa & 6.565839 & 1.409791 & 4.66 & 0.000 & 3.802698 & 9.328979 \\
ZF & -.006091 & .7136552 & -0.01 & 0.993 & -1.404829 & 1.392647 \\
\hline /cut1 & 2.386022 & 2.223029 & & & -1.971035 & 6.743078 \\
/cut2 & 4.802019 & 2.189637 & & & .5104091 & 9.093629 \\
/cut3 & 8.417596 & 2.243873 & & & 4.019685 & 12.81551 \\
\hline
\end{tabular}

\section{Conclusions and discussion}

\subsection{Conclusions}

This paper takes 21 listed companies in Shenzhen A-share entertainment media industry and 59 listed companies in entertainment industry from 2013 to 2017 as the research samples to study the impact of executive characteristics on the quality of accounting information disclosure. According to the results of information disclosure evaluation (A, B, C, D) published by Shenzhen Stock Exchange, this paper measures the quality of accounting information disclosure of enterprises, and studies the influence on 
the quality of accounting information disclosure from four aspects: executive gender, political background, education level and age.

The conclusions are as follows:

Table 3 Hypothesis Test Results Table

\begin{tabular}{l|c}
\hline \multicolumn{1}{c|}{ Assumptions } & Regression result \\
\hline $\begin{array}{l}\text { H1: The higher the proportion of female executives, the better the quality of } \\
\text { accounting information disclosure }\end{array}$ & Support \\
\hline $\begin{array}{l}\text { H2: Executives with political background play an active role in the quality of } \\
\text { accounting information disclosure }\end{array}$ & Not supported \\
\hline $\begin{array}{l}\text { H3: The higher the level of executive education, the better the quality of } \\
\text { accounting information disclosure }\end{array}$ & Support \\
\hline $\begin{array}{l}\text { H4: The older the executives, the better the quality of accounting information } \\
\text { disclosure }\end{array}$ & Not supported \\
\hline
\end{tabular}

\subsection{Further discussion}

There are great differences between female executives and male executives in personality traits and ways of thinking. Maintaining a certain proportion of female executives in the senior management team can make the senior management team have both the caution and delicacy of female executives when they have the vision of male executives to dare to take risks and pursue development. Generally speaking, the higher the education level of senior executives is, the richer their knowledge reserve will be. The managers with higher education level will be more rational in looking at problems, and more likely to rationally analyze the environment, advantages and disadvantages and other aspects of enterprise decision-making, and choose to avoid risks. At the same time, the entertainment industry and the political intersection is relatively small, in terms of executive personal development, the existence of political background is not an important factor. Entertainment industry is a new industry which has developed in recent years. The short history of entertainment industry makes its requirement for experience lower, and the rapid renewal of personnel in the industry and the younger age of leaders of modern social development lead to the generally low age of executives in enterprises.

In recent years, the business loopholes of the entertainment industry emerge endlessly, all kinds of signs indicate the immaturity and instability of this new industry, coupled with tax evasion and evasion in the entertainment industry, and illegal means to obtain profits often occur, so it is necessary to study the characteristics of entertainment industry executives and the quality of corporate accounting information disclosure; In addition, the study can also help companies to find a reasonable management team configuration model, so as to improve the quality of accounting information, further promote the entertainment industry collection and management information construction, strengthen horizontal links, and implement hierarchical management. This paper puts forward a new research perspective. Previous studies are from all listed companies system analysis, and this paper has important theoretical significance based on the particularity of the emerging entertainment industry, to study the relationship between the personal characteristics of executives and the quality of corporate accounting information disclosure.

\subsection{Limitations}

At present, there is only one evaluation method for the quality of accounting information in Shenzhen Stock Exchange. Influenced by many factors, the stability test can't be carried out at this stage. In the follow-up study, the stability test will be improved; Data is small. The entertainment media industry mainly studied in this paper has a short development period and the number of listed companies is small, which makes the data volume small. In the later study, we will consider extending the time span to obtain more data. 


\section{References}

[1] Wu Qinya, Wang Mei. The influence of executives' personal characteristics on the quality of accounting information disclosure--An empirical study based on listed companies in the information technology industry [J]. Friends of Accounting, 2018, 11: 63-67.

[2] Peng Chen, Zheng Linlin, Li Xiaotong. The Relationship between Executive Political Connectivity and Corporate Performance: A Study Based on the Sinicization of Marxism [J]. Management Watch, 2018, 31: 41-43.

[3] FORTE A.Antecedents of managers' motal reasoning[J]. Journal of Business Ethics, 2004, 51(4): 315-347.

[4] Cheng Jiyang. Research on Identification and Governance of Financial Fraud in Listed Companies [J]. Accounting for Rural Enterprises in China, 2018, 08: 206-208.

[5] Gibbs, M., K. Merchant, W. Van der Stede, M. Vargus. Determinants and Effects ofSubjectivityin Incentives. University ofSouthern California, WorkingPaper, 2003. 